\title{
A Review on Benefits and Disadvantages of Tree Diversity
}

\author{
Markku Larjavaara*
}

Smithsonian Tropical Research Institute, Panama

\begin{abstract}
This paper presents the benefits and disadvantages of tree diversity in forestation. Maintaining diversity of trees in forestation enhances the conservation of trees and other organisms, decreases production risks and increases the possibility of natural regeneration. The value of forest products may be increased or decreased, but increasing diversity always complicates forest management. Species diversity could be increased by encouraging forest owners and managers to mix species; in order to achieve this, scientific information on lesser-known species and silviculture of mixtures must be compiled and disseminated.
\end{abstract}

\section{INTRODUCTION}

The structure of forests and their use varies drastically around the world. The common uniting theme in forest science has been timber production. However, in the most recent decades, other forest products and services than timber have gained relative importance. Researchers have realized that gathering in natural forests is crucial for survival of millions of poor in the developing countries and people in rich countries have started to appreciate recreational and biodiversity values. Therefore, the trend of decreasing natural forests and increasing exotic monocultural plantations optimized only for timber production has triggered a debate in many countries around the world. People have demanded conservation of natural forests and modifications in plantation forestry.

The naturalness of planted forests can be increased by using indigenous tree species and by mixing several species. These two possibilities are often discussed together. However, discussing them together can cause confusion as the mechanisms in which they influence the yield of products and services are different. When the focus is only on diversity, the mechanisms of influence are common around the world at the theoretical level. Despite this, I am not aware of a review covering most or all the benefits and disadvantages of tree diversity on forestation (both reforestation and afforestation) success. In this short review, I aim presenting mechanisms in which inter- and intra-specific tree diversity influences forestation success. The intention is not to review all relevant literature but to categorize the mechanisms in a comprehensive way and cite relevant examples.

Inter-specific diversity refers to the variability between species and intra-specific diversity to the variability between individuals within a species. The focus of this article is on genotypic tree variability within a forest (or stand) at a given time thus including both intra- and inter-specific diversity. Yet some of the information presented is also relevant to variability caused by the environment, at the landscape level or over time at a given location. Especially in non-scientific

*Address correspondence to this author at the Smithsonian Tropical Research Institute, Panama; E-mail: LarjavaaraM@si.edu literature, benefits of biodiversity and vegetation cover are often confused. For example, erosion control is sometimes mentioned as one of the benefits of biodiversity, even though the level of erosion is dependent on the vegetation structure and not directly on the diversity of plants [1].

\section{BENEFITS OF DIVERSITY}

If the aim of forestation is to conserve biodiversity of trees, it is obvious that maximizing inter- or intra-specific diversity of trees planted, sown or naturally regenerated is vital. The justification for biodiversity conservation is well presented in numerous publications [2, 3], which focus on the economic values of diversity such as potential use in agriculture and the pharmaceutical industry, or on ethical and aesthetic concerns. It is often stressed that biodiversity should be conserved in nature in order to enable natural evolution, however it is equally important to emphasize that without intra-specific diversity, natural evolution is impossible.

A higher number of tree species increases the number of ecological niches and has also been shown to increase the number of associated species such as understory plants [4] and animals [5]. Therefore, planting numerous tree species on a site not only conserves more trees but other organisms as well.

While biodiversity conservation confers benefits at the global level, most impacts of tree diversity in forestation are local. Over 800 million humans live in the tropical forests and woodlands [6] and often rely on the wide range of food, medicinal plants or other products they can gather from forests. Similarly as foraging animals that benefit from diverse forests also smallholders who collect for their own use benefit more from diverse forests as it is better for them to be able to harvest small quantities of numerous products than an abundance of just one or two. However, as with biodiversity conservation, private forest owners may not have incentives to provide non-timber forest products for local people.

A greater diversity of trees considerably decreases the risks associated with forestation. For example, inter- or intraspecific variability in tolerance to biotic and abiotic stresses increases the probability that a small proportion of trees die but lower the risk of all of them dying. This is beneficial as the 
value of a living tree is normally the higher the less there are trees remaining and in many cases, a portion of trees dying is only beneficial for stand development. Diversity increases the likelihood that at least one species will produce well, if little of the species or the site conditions is known, or if the conditions are changing [7]. This effect has been called "insurance hypothesis" in ecological literature especially in relation to climate change [7].

Diversity can also decrease the risk of tree mortality or stagnation as a result of spatially spread agents [8]. Pests or pathogens requiring proximity to host trees cannot infect trees surrounded by non-host trees belonging to a species or genotype that is not susceptible $[9,10]$. In the same way, non-flammable and tightly rooted trees can protect their neighbours in a forest fire [11] or strong wind [12]. However, easily flammable or unstable trees at the same time increase the risk of damage of their more hardy neighbors.

Theoretically, the more diverse a forest is, the more random is the pattern of dead trees after a disturbance. In a monoculture, a spreading disturbance such as disease or fire often kills a cluster of trees from one area and leave other areas untouched [13]. The spatial pattern could be similarly aggregated after a non-spreading disturbance such as drought, if there is variability in edaphic conditions. The more diverse the forest is, the more random is the pattern of dead trees and the less harmful the disturbance will be, even if proportion of dead trees is the same. This is because surviving individuals that benefit from the increased availability of resources because their neighbor is eliminated, are more numerous in a more random and less clustered mortality pattern. In fact, their spatial pattern can be similar to that of individuals removed in anthropogenic thinnings.

The risks related to uncertain values of timber and nontimber forest products are lower in diverse stands containing a large range of products. In addition, the composition of diverse stands can be changed by selectively thinning only certain species or genotypes if their value drops unexpectedly.

Plant ecology theories suggest that competition between individuals of the same species is more intense than competition between individuals of different species [14]. Kelty [15] divided these mechanisms into "complementary resource use" springing up from stratification in canopies or roots and more efficient resource use and "facilitative improvement in nutrition" related to nitrogen fixing species benefiting other species (for e.g. see [16]). Furthermore, ratios of nutrients uptake vary between species [17] and some soils might not be able to support a monoculture of a species requiring plenty of the particular element. Because of these reasons, the productivity of e.g. timber, carbon or fruits, of a mixture of trees is often higher on average than that of monocultures $[18,19]$. In the same way, intra-specific diversity could also increase productivity of tree stands.

Mixed plantations enable numerous silvicultural techniques that are not possible or feasible in a monoculture. For example, trees can be planted or thinned out at different times. Seedling of many valuable tree species cannot survive in the open but requires shelter trees to adjust microclimate and control weeds (for e.g. see [20]). Even if the seedlings of valuable trees perform best in full sunlight, they might re- quire a dense even-aged stand to produce good quality timber [15]. This is often best achieved by mixing it with another species yielding early and perhaps regenerating naturally. This secondary species can be later thinned out to release resources for the more valuable species requiring a longer rotation period.

It is obvious that the functional variability resulting from inter-specific diversity is much greater than of intra-specific diversity. As most of the benefits of diversity are dependent on the extent of functional variability, inter-specific diversity is much more beneficial for example to reduce risks. However, self-incompatibility and inbreeding depression are restricted to low intra-specific diversity and have nothing to do with inter-specific diversity. Genetically, similar plants such as siblings of some species cannot produce seeds due to selfincompatibility, making regeneration in an isolated stand with low intra-specific diversity impossible [21]. Even if seeds are produced, their quantity or quality may be reduced or the viability of the new generation significantly altered as a result of inbreeding depression [22]. In addition, interspecific diversity increases the sustainability of rehabilitation: the more tree species present with the potential to reproduce, the higher the likelihood that viable undergrowth will develop; thanks to the variability of sprouts and seedlings.

\section{DISADVANTAGES OF DIVERSITY}

Although the benefits of forest trees diversity in forestation are numerous, a majority of the world's tree plantations are monocultures [23], and many are established with little intra-specific diversity [24]. One of the reasons for this is that planting a monoculture with only one strongly bred or naturally adapted and genetically narrow variety enables the use of the best genotype of the best species whereas increasing diversity inevitably requires the inclusion of inferior genotypes or species. Even if a mixed stand performs better on average for any of its components individually, it can be outperformed by a monoculture of a highly bred variety $[25$, 26].

A totally different mechanism is via allelopathy. There is some evidence that chemical interaction between species have an adverse effect on growth [26]. Little is known however, on its importance, but it is presumably low.

Inter-specific diversity also complicates forest management [14]. Management procedures, starting from seed handling, are different for different species. Existing research is often focused on economically important tree species with well-developed monoculture management regimes [14]. The possible combinations of species for mixtures are innumerable and optimal management is dependent on the proportions of trees in the mixtures - simply having a stable mixture and keeping all the species alive can be challenging, especially if some species grow faster than others [27].

As already stated, diversity is beneficial to communities gathering for their own use, as for them the marginal value of a forest product normally decreases with increasing quantity harvested. However, when products are harvested for sale, their marginal value often increases with increasing quantity. For example, assuming the same timber market price for all species, it would be more profitable to harvest a monoculture than harvesting numerous species in quantities 
too small for efficient harvesting, transporting and marketing. Even if the marginal value of a product decreases with increasing quantity, it might be preferable to focus on producing one or only a few products using a monoculture if their value is significantly higher than products obtained from other tree species.

\section{CONCLUSIONS}

Ensuring diversity of trees in forestation enhances biodiversity conservation, decreases risks in the production of timber and non-timber forest products, and increases natural regeneration in the rehabilitated forests. While the productivity and value of the products produced may be either increased or decreased, increasing trees diversity complicate forest management. For this reason, monocultures are favored for timber production most plantations around the world. When biodiversity conservation is emphasized, however, polycultures are planted. In developing countries, free access to diverse rehabilitated forests provides rural people with food, medicines and other non-timber products that were once routinely gathered from natural forests. More research for example based on permanent plots on lesser used species and growing mixtures should be undertaken in order to change attitudes and encourage forest managers to use diversity and to meet the challenges involved with managing diverse stands.

\section{ACKNOWLEDGEMENTS}

I want to thank anonymous reviewers, Nghia N. H., Anto Rimbawanto, Lex Thomson and Enrique L. Tolentino for comments on the manuscript and HSBC Climate Partnership for financial support. I prepared the first version of the article as an employee of Bioversity International.

\section{REFERENCES}

[1] Renard KG, Foster GR, Weesies GA, et al. RUSLE - revised universal soil loss equation. J Soil Water Conserv 1991; 46: 30-3.

[2] Frankham R, Ballou JD, Briscoe DA. Introduction to conservation genetics. Cambridge University Press, Cambridge, UK. 2002.

[3] Pregernig M. (2006) Biodiversity in national forest and environmental policy. In: Geburek T, Turok J (eds). Conservation and management of forest genetic resources in Europe 13-32. Arbora Publishers, Zvolen, Slovakia.

[4] Kanowski J, Catterall CP, Wardell-Johnson GW, et al. Development of forest structure on cleared rainforest land in eastern Australia under different styles of reforestation. For Ecol Manage 2003; 183: 265-80.

[5] Wunderle JM Jr. The role of animal seed dispersal in accelerating native forest regeneration on degraded tropical lands. For Ecol Manage 1997; 99: 223-35.

[6] Chomitz KM, Buys P, De Luca G, et al. At loggerheads? - Agriculture expansion, poverty reduction and environment in the tropical forests. The World Bank. Washington DC, USA 2007.
[7] Loreau M, Naeem S, Inchausti P, et al. Biodiversity and ecosystem functioning: Current knowledge and future challenges. Science 2001; 294: 804-8.

[8] Vehvilainen H, Koricheva J, Ruohomaki K, et al. Effects of tree stand species composition on insect herbivory of silver birch in boreal forests. Basic Appl Ecol 2006; 7: 1-11.

[9] Chokkalingam U, Carandang AP, Pulhin JM, Lasco RD (2006). Indroduction. In: Chokkalingam U, Carandang AP, Pulhin JM, Lasco RD, Peras RJJ, Toma T (eds.) One century of forest rehabilitation in the Philippines: approaches, outcomes and lessons 1-5. Center for International Forestry Research (CIFOR), Bogor, Indonesia.

[10] Linden M, Vollbrecht G. Sensitivity of Picea abies to butt rot in pure stands and in mixed stands with Pinus sylvestris in southern Sweden. Silva Fenn 2002; 36:767-78.

[11] Holdo RM. Stem mortality following fire in Kalahari sand vegetation: effects of frost, prior damage, and tree neighbourhoods. Plant Ecol 2005; 180: 77-86.

[12] Schutz JP, Gotz M, Schmid W, et al. Vulnerability of spruce (Picea abies) and beech (Fagus sylvatica) forest stands to storms and consequences for silviculture. Eur J For Res 2006; 125: 291-302.

[13] Preisler HK. Modeling spatial patterns of trees attacked by barkbeetles. Appl Stat 1993; 42: 501-14.

[14] Hooper DU, Chapin III FS, Ewel JJ, et al. Effects on biodiversity on ecosystem functioning: a consensus of current knowledge. Ecolo Monogr 2005; 75: 3-35.

[15] Kelty MJ. The role of species mixtures in plantation forestry. For Ecol Manage 2006; 233: 195-204.

[16] Forrester DI, Bauhus J, Cowie AL, et al. Mixed-species plantations of Eucalyptus with nitrogen-fixing trees: a review. For Ecol Manag 2006; 233: 211-30.

[17] Hiremath AJ, Ewell JJ, Cole TG. Nutrient use efficiency in three fast-growing tropical trees. For Sci 2002; 48: 662-72.

[18] Atta-krah K, Kindt R, Skilton JN, et al. Managing biological and genetic diversity in tropical agroforestry. Agrofor Sys 2004; 61:183-94.

[19] Erskine PD, Lamb D, Bristow M. Tree species diversity and ecosystem function: can tropical multi-species plantations generate greater productivity? For Ecol Manage 2006; 205-210.

[20] McNamara S, Duong VT, Erskine PD, et al. Rehabilitating degraded forest land in central Vietnam with mixed native species plantings. Forest Ecology and Management 2006; 233: 358-65.

[21] Byers DL, Meagher TR Mate availability in small populations of plant-species with homomorphic sporophytic self-incompatibility. Heredity 1992; 68: 353-9.

[22] Frankham R, Ballou JD, Briscoe DA, Introduction to conservation genetics. Cambridge University Press, 2002.

[23] Carle J, Vuorinen P, Del Lungo A. Status and trends in global forest plantation development. For Prod J 2002; 52: 12-23.

[24] Zheng YQ, Ennos RA. Genetic variability and structure of natural and domesticated populations of Caribbean pine (Pinus caribaea Morelet). Theor Appl Genet 1999; 98: 765-71.

[25] Lamb D, Erskine PD, Parrotta JA. Restoration of degraded tropical forest landscapes. Science 2005; 310: 1628-32.

[26] Jose S, Williams R, Zamora D. Belowground ecological interaction in mixed-species forest plantations. For Ecol Manage 2006; 233: 231-9.

[26] McKay JK, Christian CE, Harrison S, et al. How local is local?: a review of practical and conceptual issues in the genetics of restoration. Restor Ecol 2005; 13: 432-40.

[27] Erskine PD, Lamb D, Borschmann G. Growth performance and management of a mixed rainforest tree plantation. N For 2005; 29:117-34 